\title{
KONSEP DIRI DAN RASA BERSALAH PADA ANAK DIDIK LEMBAGA PEMASYARAKATAN ANAK KELAS IIA KUTOARJO
}

\author{
Retno Ristiasih Utami \\ Martha Kurnia Asih \\ Fakultas Psikologi Universitas Semarang
}

\begin{abstract}
Abstrak
Penelitian ini bertujuan untuk mengetahui hubungan antara Rasa Bersalah dan Konsep Diri serta apakah Rasa Bersalah bisa diprediksi melalui Konsep Diri pada anak didik Lembaga Pemasyarakatan Anak (Lapas) Kelas II A Kutoarjo. Metode pengumpulan data dengan menggunakan alat ukur Skala Rasa Bersalah dan Skala Konsep Diri. Populasi penelitian sebanyak 72 orang anak didik yang diambil sampelnya dengan teknik Incidental Sampling sebanyak 41 orang, usia antara 1318 tahun. Data dianalisis dengan teknik Analisis Regresi Sederhana, diperoleh hasil $\mathrm{R}_{\mathrm{xy}}=0,035$ dengan $\mathrm{p}>0.05$ Hasil penelitian menunjukkan bahwa tidak ada hubungan antara Rasa Bersalah dan Konsep Diri pada anak didik di Lapas Anak Kelas II A Kutoarjo sehingga Rasa Bersalah tidak dapat diprediksi berdasarkan Konsep Diri.
\end{abstract}

Kata kunci : Rasa Bersalah, Konsep Diri, Anak Didik Lembaga Pemasyarakatan Anak

\begin{abstract}
The purpose of this study is to examine the correlation between guilty feeling and self concept of prisoners from Kutoarjo Children Penitentiary. Analysis of regression is used to analyze data that conducted with Guilty Feeling and Self Concept Scale. Population of this research is 72 prisoners from Kutoarjo Children Penitentiary, the subjects were determined through an incidental sampling technique $(n=41), 13-20$ years, male and female. Result reveal that it was no correlation between guilty feeling and self concept $\left(R_{x y}=0.035\right.$ and $\left.p>0.05\right)$ so, guilty feeling can't be predicted by self concept of prisoners from Kutoarjo Children Penitentiary.
\end{abstract}

Keywords : personalitydisorder, prisoners from Children Penitentiary 


\section{Pendahuluan}

Remaja merupakan usia di mana seseorang mengalami suatu masa peralihan antara masa kanak-kanak dan dewasa. Remaja yang sebagian menjadi narapidana yang dididik di Lapas-Lapas khusus untuk anak dan remaja, akan mengalami berbagai tekanan dan proses penyesuaian diri. Anak didik tersebut merupakan pelaku tindak kriminal dan mendapat pembinaan di Lapas khusus. Remaja yang dididik di Lapas Anak juga mempunyai masalah, seperti masalah penyesuaian diri, beragama, kesehatan, ekonomi, seksual, keluarga dan pendidikan (Anwar \& Adang, 2010). Remaja yang baru pertama kali menjalani hukuman dituntut untuk mampu beradaptasi dan bersosialisasi dengan peraturan Lapas yang sangat menekan, rutinitas kehidupan sosial bersama dengan narapidana lain yang sering menimbulkan keributan, pemerasan dan tindak kekerasan yang dirasakan sebagai suatu penderitaan lain disamping hukuman sendiri.

Di Indonesia, jumlah anak-anak yang berhadapan dengan hukum cukup banyak seperti data yang di himpun oleh Dirjen Pemasyarakatan Depkumham jumlahnya mencapai kurang lebih 60 ribu anak, jumlah anak yang berhadapan dengan hukum banyak terjadi pada wilayah dengan jumlah penduduk padat seperti Jawa dan Sumatera, berdasarkan data tersebut tertinggi terjadi di 5 wilayah provinsi yaitu, Jawa Tengah, Sumatera Utara, DKI Jakarta, Jawa Timur dan Jawa Barat. Jawa Tengan merupakan provinsi dengan peringkat nomor satu tingkat kriminal yang dilakukan oleh anak, namun hanya memiliki satu Lembaga Pemasyarakatan Anak, yaitu Lembaga Pemasyarakatan Anak Kutoarjo, hal ini tentunya menjadi perhatian penting mengingat bahwa tingkat kriminalaitas yang dilakukan anak dibawah umur di Jawa Tengah masih tinggi. Kenakalan anak atau tindak pidana anak harus menjadi perhatian serius oleh negara dan harus disadari bahwa anak pada hakikatnya merupakan generasi penerus bangsa yang memiliki keterbatasan dalam memahami dan melindungi diri dari berbagai pengaruh sistem yang ada. Anak perlu bantuan orang lain dalam melindungi dirinya, mengingat situasi dan kondisinya, khususnya dalam pelaksanaan peradilan pidana anak yang asing bagi dirinya. Anak perlu mendapat perlindungan dari penerapan peraturan PerundangUndangan yang diberlakukan terhadap dirinya, yang menimbulkan kerugian mental, fisik, dan sosial. Karena itulah negara dalam tanggung jawabnya harus memberikan perlindungan kepada anak, ketika anak melakukan tindak pidana melalui berbagai peraturan perundangundangan diantaranya UU No. 3 Tahun 1997 tentang Pengadilan Anak, UU No. 39 Tahun 1999 tentang Hak Asasi Manusia, UU No. 23 Tahun 2002 tentang Perlindungan Anak, dan UU No. 11 Tahun 2012 tentang Sistem Peradilan Pidana Anak.

Faktor-faktor yang menjadi penyebab mereka melakukan tindak kriminal adalah faktor lingkungan (teman sebaya) dan keluarga (Savitri \& Utami, 2012). Kecenderungan remaja untuk berbuat kriminal kebanyakan disebabkan kondisi eksternal, bukan dorongan kesadaran diri. Menyedihkan ketika mereka dimasukkan ke dalam Lapas yang sebetulnya berfungsi sebagai tempat atau proses pembinaan tetapi di beberapa Lapas belum berfungsi sebagai tempat untuk memperbaiki masa depan anak didiknya. Data dunia menyebutkan bahwa $50 \%$ sampai dengan $70 \%$ remaja yang dibebaskan 
dari Lapas itu menjadi residivis (Distia, 2008 dalam Yulianti, dkk, 2009).

Anak didik Lapas Anak yang dikategorikan berusia remaja masih memiliki harapan panjang untuk dapat memperbaiki perilakunya. Meskipun kepibadian seseorang di masa remaja mengalami lebih banyak perubahan dibandingkan di masa dewasa namun stabilitas kepribadian di masa remaja itu masih tetap ada. (Santrock, 2007). Rasa bersalah merupakan efek dari remaja nakal yang dianggap merupakan suatu pelanggaran terhadap sistem nilai yang ada pada masyarakat umumnya, apalagi rasa bersalah tersebut muncul dalam kehidupan setiap orang. Menurut Chaplin (dalam Windi, 2010), perasaan emosional yang berasosiasi dengan realisasi bahwa seseorang telah melanggar peraturan sosial, moral atau etika dapat menimbulkan rasa bersalah.

Bila rasa bersalah muncul dalam diri pelaku maka akan ada kemungkinan munculnya penyesalan pada diri mereka. Hal ini karena remaja nakal, terlebih yang telah melakukan tindak kriminalitas dianggap telah melakukan suatu pelanggaran terhadap standar internal individu serta merupakan pelanggaran terhadap peraturan sosial, moral atau etika yang ada dalam masyarakat, maka kaan ada kemungkinan munculnya penyesalan pada diri mereka. Penyesalan tersebut diharapkan pada akhirnya dapat membawa perubahan sehingga mereka meninggalkan perbuatan melanggar tersebut.

Kualitas konsep diri seseorang akan berkaitan dengan pemikiran, persepsi dan perbuatan. Konsep diri bersifat sebagai kerangka acuan dalam mempengaruhi individu saat berhadapan dengan situasi interaksi dengan orang lain. Komponen konsep diri yang terdiri atas citra tubuh, harga diri, identitas diri dan penampilan peran akan berpengaruh pada perilaku.
Intervensi dapat dilakukan bila diperoleh data yang akurat mengenai subjek. Pembinaan dan pendidikan di Lapas Anak juga dapat dilakukan apabila diperoleh gambaran mengenai latar belakang perilaku dan aspek-aspek psikologis anak didik tersebut. Remaja sebagai individu yang masih berada dalam masa transisi menuju kedewasaan tentu saja rentan dengan kondisi yang ada dalam Lapas. Salah satu aspek emosional yang harus ditumbuhkan dalam diri anak didik Lapas anak adalah rasa bersalah sehingga diharapkan juga menimbulkan penyesalan akan perbuatan yang telah mereka lakukan. Berapa besarnya kontribusi konsep diri untuk menimbulkan rasa bersalah tersebut merupakan pertanyaan penelitian yang hendak dijawab. Hasil dari penelitian ini diharapkan akan membantu menentukan intervensi yang tepat untuk mengatasi permasalahan yang timbul pada diri mereka. Berdaarkan rumusan masalah yang sudah diuraikan di atas maka pertanyaan penelitian yang diajukan adalah : Apakah ada hubungan antara rasa bersalah dan konsep diri serta apakah rasa bersalah dapat diprediksi berdasarkan konsep diri pada anak didik Lapas Anak Kelas II A Kutoarjo ?

\section{Kajian Pustaka}

\section{a. Rasa bersalah}

Rasa bersalah adalah emosi introspektif yang merupakan hasil dari refleksi diri dan peristiwa negatif (Baumeister, dkk, 2007). Hal ini menjelaskan bahwa terdapat ketidaksesuaian antara perilaku diri terhadap apa yang telah dilakukan dan membuat suatu keadaan yang tidak diinginkan. Pendapat tersebut senada dengan yang diungkapkan oleh $\mathrm{Xu}$, dkk (2011) bahwa rasa bersalah adalah penerimaan diri yang tidak dikehendaki 
atau tidak diinginkan. Rasa bersalah juga merupakan keadaan emosi negatif yang timbul ketika tingkah laku individu berselisih dengan standardisasi tingkah laku yang seharusnya.

Menurut Tangney (dalam Cohen, dkk, 2010) rasa bersalah dapat ditunjukkan dengan adanya kecenderungan untuk mengevaluasi perilaku diri yang negatif dan kecenderungan untuk memperbaiki keadaan. Rasa bersalah adalah suatu pemahaman yang berpusat pada diri individu yang memiliki tanggungjawab atas tindakannya dan bersifat bebas yang merupakan ciri fundamental dari kemampuan individu untuk memaknai hidupnya.

Berdasarkan beberapaa pengertian di atas maka dapat disimpulkan bahwa rasa bersalah adalah emosi negatif yang muncul dari kesadaran diri, refleksi diri dan evaluasi terhadap suatu tindakan yang tidak seharusnya dan memunculkan peristiwa negatif karena adanya ketidaksesuaian antara tindakan dengan nilai, norma dan moral yang berlaku dalam masyarakat dan pada akhirnya dapat mendorong individu untuk memperbaiki perilakunya.

Ada beberapa perilaku yang dapat dijadikan indikator dari rasa bersalah, yaitu (1). Merasa bertanggungjawab terhadap keadaan negatif yang terjadi pada dirinya dan orang lain (2). Merasa menyesal terhadap kenyataan atau membayangkan tentang kelakuan buruk. (3). Perasaan menyesal yang sangat mendalam yang tidak diterima oleh diri sendiri dan orang lain. (4). Memiliki perasaan moral yang kuat akan kesalahan dan kebenaran. (5). Berperilaku dengan terpaksa atau bersembunyi pada kepercayaan yang tidak logis.

\section{b. Konsep Diri}

Pengertian konsep diri adalah gambaran atau pandangan terhadap diri sendiri yang mencakup pemikiran, persepsi dan perbuatan. Konsep diri adalah semua ide, pikiran, kepercayaan dan pendirian yang diketahui individu tentang dirinya dan mempengaruhi individu dalam berhubungan dengan orang lain (Potter \& Perry, 2009). Menurut Burns (1982) konsep diri adalah hubungan antara sikap dan keyakinan tentang diri sendiri, termasuk sikap, perasaan, persepsi, nilai-nilai dan perilaku yang unik dari individu tersebut. Santrock (2007) menggunakan istilah konsep diri yang mengacu pada evaluasi bidang tertentu dari individu sehingga muncul pula istilah konsep diri akademik.

Berdasarkan beberapa teori di atas dapat disimpulkan bahwa konsep diri adalah kumpulan keyakinan dan persepsi diri mengenai diri sendiri yang terorganisasi, dengan kata lain konsep diri tersebut bekerja sebagai skema dasar. Konsep diri memberikan sebuah kerangka berpikir yang menentukan bagaimana mengolah informasi tentang diri sendiri, termasuk motivasi, keadaan emosional, evaluasi diri, kemampuan dan banyak hal lainnya.

Komponen yang membentuk konsep diri adalah citra tubuh, ideal diri, harga diri, identitas diri dan penampilan peran. Citra tubuh adalah sikap terhadap atribut fisik individu, karakteristik penampilan dan kinerja. Stuart \& Sundeen (dalam Ihsani, 2015) menyebutkan bahwa sikap ini mencakup persepsi dan perasaan tentang ukuran, bentuk, fungsi penampilan dan potensi tubuh saat ini dan masa lalu yang secara berkesinambungan dimodifikasi dengan pengalaman baru setiap individu.

Ideal diri adalah persepsi individu tentang bagaimana ia harus berperilaku berdasarkan standar, aspirasi, tujuan atau penilaian personal tertentu. Standar dapat berhubungan dengan tipe orang yang diinginkan atau sejumlah aspirasi, citacita, nilai-nilai yang ingin dicapai. 
Harga diri adalah rasa seseorang mengenai dirinya. Rasa ini adalah suatu evaluasi dimana individu mempertahankan dirinya, merupakan penilaian pribadi terhadap hasil yang dicapai dengan menganalisis seberapa jauh perilaku memenuhi ideal diri. Frekuensi pencapaian tujuan akan menghasilkan harga diri yang rendah atau tinggi. Jika individu sering gagal maka cenderung harga diri rendah. Harga diri diperoleh dari diri sendiri dan orang lain. Aspek utama adalah dicintai dan menerima penghargaan dari orang lain (Stuart \& Sundeen dalam Ihsani, 2015)

Identitas diri adalah sensasi individualitas dan keunikan yang disadari dan secara kontinu muncul sepanjang hidup yang merupakan bagian dari konsep diri. Identitas adalah pengorganisasian prinsip dari kepribadian yang bertanggungjawab terhadap kesatuan, kesinambungan, konsistensi dan keunikan individu.

Penampilan peran adalah sekumpulan harapan mengenai bagaimana individu menempati suati posisi tertentu dari perilaku. Peran adalah serangkaian pola perilaku yang diharapkan oleh lingkungan sosial berhubungan dengan fungsi individu di berbagai kelompok sosial. Peran yang ditetapkan adalah peran di mana seseorang tidak mempunyai pilihan. Peran yang diterima adalah peran yang terpilih atau dipilih oleh individu. Peran adalah sikap atau perilaku nilai serta tujuan yang diharapkan dari seseorang berdasarkan posisinya di masyarakat (Santrock, 2007).

Menurut Berk (dalam Dariyo, 2007) konsep diri ialah gambaran diri sendiri yang bersifat menyeluruh terhadap keberadaan diri seseorang. Konsep diri ini bersifat multi-aspek yaitu meliputi 4 (empat) aspek seperti : (1). Aspek fisiologis, (2). Aspek psikologis, (3). Aspek Psikososiologis, (4). Aspek psiko- etika dan moral. Gambaran konsep diri berasal dari interaksi antara diri sendiri maupun antara diri dengan orang lain atau lingkungan sosialnya. Oleh karena itu konsep diri merupakan cara pandang seseorang mengenai diri sendiri untuk memahami keberadaan diri sendiri maupun memahami orang lain.

Berdasarkan teori-teori yang telah dikemukakan maka dapat ditarik simpulan bahwa komponen konsep diri terdiri dari komponen fisiologis, psikologis dan sosial.

Berdasarkan tinjauan pustaka yang telah dilakukan maka simpulan sementara yang dapat diajukan adalah ada hubungan antara Rasa Bersalah dan Konsep Diri pada anak didik Lembaga Pemasyarakatan Anak Kelas II A Kutoarjo. Rasa bersalah dapat diprediksi berdasarkan Konsep Diri Anak didik tersebut.

\section{Metode Penelitian}

Variabel tergantung dari penelitian ini adalah rasa bersalah sedangkan variabel bebas adalah konsep diri. Metode Pengumpulan Data yang digunakan dalam penelitian ini adalah metode kuesioner dengan alat ukur Skala Rasa bersalah dan Skala Konsep Diri. Populasi penelitian ini adalah anak didik di Lapas Anak Kl II A Kutoarjo sebanyak 72 orang, sampel sebanyak 41 orang diambil dengan teknik insidental sampling.

Analisis data yang digunakan adalah teknik analisis regresi sederhana non linier dengan SPSS 17.00.

\section{Hasil dan Pembahasan}

Hasil perhitungan dengan teknik Regresi sederhana non linier adalah sebagai berikut : 
Tabel 1.

Hasil Analisis Regresi Sederhana Non Linier

\section{Model Summary and Parameter Estimates}

Dependent Variable: rasabersalah

\begin{tabular}{|c|c|c|c|c|c|c|c|}
\hline $\begin{array}{c}\text { Eq } \\
\text { uat } \\
\text { ion }\end{array}$ & \multicolumn{6}{|c|}{ Model Summary } & \multicolumn{2}{|c|}{$\begin{array}{c}\text { Paramet } \\
\text { er } \\
\text { Estimate } \\
\text { s }\end{array}$} \\
\cline { 2 - 7 } & $\begin{array}{c}\text { R } \\
\text { Squ } \\
\text { are }\end{array}$ & F & df1 & df2 & Sig & $\begin{array}{c}\text { Co } \\
\text { nst } \\
\text { ant }\end{array}$ & b1 \\
\hline $\begin{array}{c}\text { Lin } \\
\text { ear }\end{array}$ & $\begin{array}{c}03 \\
5\end{array}$ & $\begin{array}{c}1,4 \\
06\end{array}$ & 1 & 39 & $\begin{array}{c}, 24 \\
3\end{array}$ & $\begin{array}{c}16, \\
432\end{array}$ & $\begin{array}{c}, 19 \\
8\end{array}$ \\
\hline
\end{tabular}

The independent variable is konsepdiri.

Berdasarkan hasil analisis dapat diketahui bahwa ternyata tidak ada hubungan antara Rasa Bersalah dengan Konsep Diri sehingga Rasa Bersalah juga tidak dapat diprediksi berdasarkan Konsep Diri Subjek. Hal tersebut ditunjukkan dengan nilai $p>0,05(p=0,243)$. Hasil tersebut menunjukkan bahwa Hipotesis alternatif yang diajukan ditolak.

Berdasarkan analisis statistik yang telah dilakukan maka dapat diketahui bahwa tidak ada hubungan antara Rasa Bersalah dan Konsep Diri pada anak didik Lapas Anak Kelas II A Kutoarjo yang menjadi sampel penelitian ini. Penelitian yang dilakukan oleh Sulistyani (2010) tentang Stress dan Konsep iri pada Narapidana Remaja di Lapas Anak Kelas II A Kutoarjo menyebutkan bahwa kemampuan penerimaan pada keadaan sebagai seorang narapidana dapat dilakukan melalui pengenalan konsep dirinya. Remaja narapidana yang memiliki konsep diri positif akan mampu berkembang dengan baik dan bertahan terhadap gangguan fisik dan psikologis. Konsep diri positif ditunjukkan dengan sikap optimis, percaya diri dan sikap positif terhadap segala sesuatu termasuk kegagalan. Kegagalan akan dipandang sebagai pelajaran berharga untk melangkah ke masa depan. Kegagalan juga dapat menimbulkan konsep diri yang negatif, merasa dirinya tidak berguna dan takut tidak diterima masyarakat. Dukungan sosial sebagai faktor eksternal nampaknya juga memegang peranan penting dalam pengembangan konsep diri. Rasa bersalah akan muncul bila ada kesadaran moral pada remaja, kesadaran bahwa apa yang dilakukannya tidak sesuai dengan harapan sosial, bila kesadaran moral tersebut tidak ada atau tidak ditumbuhkan maka rasa bersalah tidak akan muncul dan remaja akan cenderung menyalahkan lingkungan sebagai faktor penyebab perilaku salah mereka sehingga keterkaitan antara rasa bersalah dan konsep diri pada remaja narapidana relatif kecil.

Penelitian Manik (2008) dengan subjek narapidana remaja di lapas anak Tanjung Gusta Medan menunjukkan bahwa faktor-faktor yang mempengaruhi konsep diri yaitu reaksi dari orang lain, peran individu, identifikasi terhadap orang lain tidak berhubungan dengan pembentukan konsep diri. Usia remaja yang merupakan usia pembentukan konsep diri memerlukan peninjauan dari banyak faktor lagi sehingga seringkali reaksi dari orang lain terhadap perilaku remaja dipandang sebagai sebab munculnya perilaku kriminalitas remaja tersebut sehingga remaja cenderung menyalahkan lingkungan dan tidak melakukan introspeksi dan penilaian terhadap diri sendiri.

Menurut Cohen \& George (2010) tidak merasa bersalah pada dasarnya memiliki proses yang sama dengan merasa bersalah. Apabila rasa bersalah berkaitan dengan moral dan religiusitas maka tidak bersalah juga berkaitan dengan moral dan religiusitas. Seperti 
yang dikatakan oleh Kohlberg (Santrock, 2007) pelaku kriminalitas memiliki tahap perkembangan moral yang rendah yaitu pada tahap pra-konvensional. Tahap ini dialami oleh anakusia 9-11 tahun dan biasanya individu memiliki pemikiran dan nilai-nilai moral yang terdiri atas "lakukan" dan "jangan lakukan". Individu yang berusia di atas 18 tahun menurut Kohlberg sudah seharusnya berada pada tahap perkembangan moral konvensional dan post-konvensional. Pada tahap konvensional individu meyakini dan mengadopsi nilai-nilai dan aturan masyarakat. Lebih jauh lagi individu berusaha menegakkan aturan yang berlaku dalam masyarakat tersebut. Sedangkan pada tahap post-konvensional individu secara kritis menguji kebiasaan dan aturan sosial sesuai denga perasaan tentang hak-hak asasi universal, prinsipprinsip moral dan kewajiban-kewajiban yang dimiliki. Tahap ini dialami oleh individu pada usia 20 tahun ke atas.

Individu yang merasa tidak bersalah atas suatu tindak pelanggaran dapat disebabkan adanya kekerasan dan agresi melalui peniruan dan modeling atau berperilaku melalui peniruan tingkah laku orang lain, jadi merupakan tingkah laku secara sosial yang ditransmisikan melalui contoh-contoh yang terutama datang dari keluarga, sub-budaya dan media massa. Tidak merasa bersalah jugadapat diakibatkan pada pemberian penghargaan dan hukuman. Jika perilaku kriminal mendatangkan hasil positif seperti sebuah penghargaan atau ganjaran maka individu akan terus mempertahankan tindakan yang salah itu sehingga kesalahan tersebut bukan lagi menjadi sebuah tindakan yang salah.

Narramore (2005) menyebutkan bahwa apabila rasa bersalah dipengaruhi oleh pemahaman tentang kebenaran dan kesalahan dalam melakukan tindakan maka tidak merasa bersalah juga dipengaruhi oleh pemahaman tentang kebenaran dan kesalahan. Selain itu individu yang melakukan pelanggaran terhadap hukum namun tidak merasa bersalah dapat disebabkan karena keberhasilannya dalam mematikan rasa bersalah atau kurangnya pengenalan terhadap agama atau nilai-nilai moral dalam masyarakat. Jadi hanya pelanggaran-pelanggaran tertentu yang menimbulkan rasa bersalah. Jika rasa bersalah masih saja tidak dapat dirasakan oleh individu maka ada kemungkinan individu mengalami satu tipe kekacauan mental yang terdiri dari psikopatik dan gangguan kepribadian antisosial.

Hal yang bersifat konstruktif metodologis nampaknya juga memberikan dampak bagi hasil penelitian ini. Jumlah item yang valid dan kurangnya rapport building antara peneliti dan subjek penelitian menyebabkan data-data yang bersifat kualitatif menjadi kurang mendukung. Jumlah item valid yang relatif kecil bisa mengakibatkan beberapa aspek tidak terwakili sehingga variabel tidak terungkap secara maksimal. Adanya social desirability pada pernyataanpernyataan dari item-item pada kedua skala juga mempengaruhi pilihan jawaban subjek sehingga juga akan berpengaruh pada validitas dan reliabilitas. Hal tersebut seharusnya dapat diantisipasi dengan melakukan prosedur penyusunan alat ukur yang berulang, melakukan beberapakali proses reviu sehingga dapat dihasilkan suatu alat ukur yang sederhana tetapi dapat mengukur dengan akurat tujuan ukurnya.

\section{Simpulan}

Hasil penelitian ini dapat disimpulkan bahwa tidak ada hubungan antara Rasa Bersalah dan Konsep Diri pada anak didik di Lembaga Pemasyarakatan Anak Kelas II A Kutoarjo sehingga Rasa Bersalah tidak 
dapat diprediksi berdasarkan Konsep Diri.

Berdasarkan hasil penelitian anak didik diharapkan dapat mengembangkan konsep diri positif dan menumbuhkan pemahaman moral sehingga akan tumbuh rasa bersalah yang diharapkan dapat memperkecil kemungkinan menjadi residivis.

Berdasarkan hasil penelitian maka para pembina dapat meningkatkan pemahamam secara personal terutama pemahaman pada aspek-aspek psikologis sehingga pembinaan dapat disesuaikan dengan kondisi yang ada. Peningkatan kualitas konsep diri dan menumbuhkan kesadaran moral untuk memberikan kesadaran bahwa perilaku anak didik tersebut salah merupakan pembinaan yang dapat dilakukan untuk memperbaiki perilaku anak didik.

Peneliti lain dapat meneliti dengan jumlah subjek yang lebih banyak sehingga gambaran yang diperoleh lebih akurat dan dapat dikombinasikan dengan alat ukur maupun pemeriksaan psikologis yang lain. Aspek-aspek lain seperti kesadaran moral dan faktor psikososial dapat diteliti sehingga menghasilkan data yang lebih akurat.

\section{Daftar Pustaka}

Adams, K. 1992. Adjusting to Prison Life, Crime and Justice, vol. 16

Anindita dan Dahlan, W.W. 2008. Pengalaman dan Penghayatan Seorang Mantan Narapidana Terhadap Kehidupan di Penjara, Jurnal Psikologi Sosial, Vol.14 no. 03

Anwar, Yesmil dan Adang. 2010. Kriminologi. Bandung : Refika Aditama
Azwar, Saifuddin, 2012, Penyusunan Skala Psikologis, Yogyakarta : Pustaka Pelajar.

Baumeister, 2007, R, F, Vohs, K, D, DeWall, C, N \& Zhang, L, 2007, How Emotion Shapes Behavior : Feedback, Anticipation and Reflection Rather Than Direct Causation, Journal Personality and Social Psychology Review, 11, p. 167-203

Cohen, T.R, Wolf, S, T, Panter, A, T, Insko, C, A, 2010, Introducing the GASP scale : a New Measure of Guilt and Shame Prononess, Journal of Personality and Social Psychology

Gultom, Maidin. 2010. Perlindungan Hukum terhadap Anak dalam Sistem Peradilan Pidana Anak di Indonesia. Bandung : Refika Aditama

Ihsani, Y, 2015, Konsep Diri, yanihsani.wordpress, http://yanihsani.wordpress.com/2 $\underline{015 / 01 / 06}$

Manik, Christa Gumanti, 2007, Analisa Faktor-Faktor yang Mempengaruhi Konsep Diri Pada Narapidana Remaja di Lembaga Pemasyarakatan Kelas II A Anak Tanjung Gusta Medan, Skripsi, Program Studi Keperawatan Fakultas Kedokteran Universitas Sumatera Utara, tidak diterbitkan

Narramore, B, 2005, Freedom from Guilty, California : Vision House

Potter, P. A, \& Perry, A. G., 2009, Fundamental of Nursing, 7th ed. St Louis : Mosby Elsevier 
Santrock, J.W. 2007. Remaja Jilid 1. Alih bahasa Benedictine Widyasinta. Jakarta : Erlangga

Savitri, A, D., Utami, R, R., 2012, Faktor-Faktor yang Menyebabkan Kenakalan Remaja pada Anak Didik Lapas Anak Kutoarjo, Jurnal Persepsi, Fakultas Psikologi Unissula Semarang

Sulistyani, Fajar, Stress dan Konsep Diri Narapidana Remaja di Lembaga Pemasyarakatan Anak Kutorjo Jawa Tengah, 2010, Naskah Publikasi, Program Studi Ilmu keperawatan Sekolah Tinggi Ilmu Kesehatan Aisyiyah Yogyakarta, tidak diterbitkan.

Syahputra, W, 2011, Faktor-Faktor yang Mempengaruhi Rasa bersalah Mahasiswa Mengakses Situs Porno, Skripsi, Fakultas psikologi UIN Syarif Hidayatullah, Jakarta, tidak diterbitkan

Utami, R.R dan Pratiwi, MM, S. 2011. Tingkat Depresi pada Narapidana Wanita : Studi Deskriptif pada Narapidana Lapas Kelas II A Semarang, Jurnal Asvattha Edisi I/IV/Agustus 2011

Windi, N, 2010, Rasa Bersalah Pada Remaja Nakal, Skripsi, Fakultas Psikologi Universitas Muhammadiyah Surakarta, tidak diterbitkan

Yulianti, Sriati, A, Widiasih, R, 2009, Gambaran Orientasi Masa Depan narapidana Remaja Sebelum dan Setelah Pelatihan di Rumah Tahanan Negara Kelas 1 Bandung, Noursing Journal of Padjajaran University, Vol. 10, no. XIX, Oktober 2008, h. 97-104
Xu, H., Begue, L., Shankland, R, 2011, Guilt and Guiltlessness, an Integrative Review, Journal Social and Personality Psychology, Vol. 5 no. 7, 440457 
Jurnal Dinamika Sosial Budaya, Volume 18, Nomor 1, Juni 2016 